\title{
Use and Impact of ICT Resources in St. Xavier's College of Education, Tirunelveli, Tamil Nadu
}

\author{
P. Viji ${ }^{1}$ and P. Balasubramanian ${ }^{2}$ \\ ${ }^{1}$ Research Scholar, ${ }^{2}$ University Librarian \& Head \\ ${ }^{1 \& 2}$ Department of Library and Information Science, Manonmaniam Sundaranar University, Tirunelveli, Tamil Nadu, India \\ E-Mail: vijistowell@gmail.com, bala_phd2010@yahoo.com
}

\begin{abstract}
ICT based resources and services are resources in which information is stored electronically and which are accessible through electronic systems and networks. EResources are one of the products of ICT. Use of Internet and $E$ resources are increasing among the students. Most of the educational materials are available mode. ICT based resources are e journals, e book, internet resources, e mail publishing, wireless publishing and web link etc. It can be seen that $80 \%$ of respondents are below 25 years of age and $20 \%$ of the respondents are aged above 25 . It is found that the $28 \%$ of the respondents were aware of $\mathrm{WWW}, 24 \%$ of respondents e-mail, $18 \%$ of the respondents was e-journal, $16 \%$ of the respondents were e-magazines and $14 \%$ of the respondents were e-book. It was found that majority of the respondents $32 \%$ are using the E-resources for their study. The above reveals that the respondents are more interested to use e-resources for their study. Some problems and difficulties of using these facilities required for accessing e-resources were indicated by the respondents. These are slow accessibility, lack of computer and lack of knowledge, $30 \%$ of respondents stated that slow accessibility and $22 \%$ of lack of computer.
\end{abstract}

Keywords: Information and Communication Technology; EResources

\section{INTRODUCTION}

Globalization and technological change-processes that have accelerated in tandem over the past fifteen years-have created a new global economy "powered by technology, fueled by information and driven by knowledge". The emergence of this new global economy has serious implications for the nature and purpose of educational institutions. The E-Resources of available in the form of CD-ROMs E-Journals, E-Books, Online Database, and OPACs which are replacing the print media. E-Resources have provided excellent opportunities to access scholarly information, which were previously features for the facilitation of libraries and its users.

\section{REVIEW OF LITERATURE}

Kandasamy S (2019) conducted a study on creating awareness among researchers through the use of online resources and promoting effective use of electronic products. He has done an empirical study based on the primary and secondary data collected from the research scholars of Manonmaniam Sundaranar University. He found out that majority scholars were male using browsing centre for accessing online information. Major respondents use google chrome as the search engine to access online information.

Maria Anna Jankowska (2004) has done a web based survey to determine usage of information and communication technologies by faculty of research and teaching. Constraints preventing the library from efficient services are discussed, and recommendations for improving existing library services and developing new ones are presented.

Mounisamy, P and Swaroopa Rani, B.S. (2005) conducted a study on "Evaluation of usage and usability of e-journals". The sample consisted of 88 respondents from National Institute of Technology, Trichy. The main aim of the study was to find out the sex, age group of respondents who use ejournals to the maximum level, to know the quantum of ejournals accessed in a month and to identify the problems while accessing e-journals.

\section{OBJECTIVES OF THE STUDY}

1. To find out the awareness of ICT based resources.

2. To find the purpose of use of ICT resources.

3. To find out the knowledge of ICT resources.

4. To find out the problems and difficulties facing by the users while using e-resources.

5. To find out the level of satisfaction of the ICT based resources.

\section{METHODOLOGY}

The present study is a survey method using a questionnaire. Random Sampling technique was used in the study. A Total number of 75 questionnaires were distributed to collect the primary data. Out of which 50 questionnaires were found usable for analysis. The general data interpretation was made with the help of percentage and average.

\section{DATA ANALYSIS AND INTERPRETATION}

TABLE I DistRIBUtion OF RESPONDENTS By AGE WisE

\begin{tabular}{|c|c|c|c|}
\hline S. No & Users & No. of respondents & Percentage \\
\hline 1. & Age Below 25 & 40 & 80 \\
\hline 2. & Age After 25 & 10 & 20 \\
\hline \multicolumn{2}{|c|}{ Total } & 50 & 100 \\
\hline \multicolumn{2}{|c|}{ Source: Primary data }
\end{tabular}


The table I shows distribution of respondents based on the age group. It is observed that $80 \%$ of respondents are in the age below 25 and $20 \%$ of the respondents are aged above 25 .

TABLE II AWARENESS OF E-RESOURCES By THE RESPONDENTS

\begin{tabular}{|l|c|c|}
\hline E-Resources & Respondents & Percentage \\
\hline E-Journal & 9 & 18 \\
\hline E-Book & 7 & 14 \\
\hline E-Magazines & 8 & 16 \\
\hline WWW & 14 & 28 \\
\hline E-mail & 12 & 24 \\
\hline Total & 50 & 100 \\
\hline \multicolumn{3}{|c|}{ Source: Primary data }
\end{tabular}

The table II shows the extent of E-resources used by the respondents. It is seen that the $28 \%$ of the respondents were aware of WWW, 24\% of respondents e-mail, $18 \%$ of the respondents was e-journal, $16 \%$ of the respondents were emagazines and $14 \%$ of the respondents were e-book.

TABLE III PuRPose Of Using E-Resources

\begin{tabular}{|l|c|c|}
\hline \multicolumn{1}{|c|}{ Purpose } & Respondents & Percentage \\
\hline To Update Subject Knowledge & 9 & 18 \\
\hline To prepare multimedia package & 7 & 14 \\
\hline To prepare digital lesson plan & 8 & 16 \\
\hline Finding relevant information & 10 & 20 \\
\hline For study & 16 & 32 \\
\hline Total & 50 & 100 \\
\hline
\end{tabular}

Source: Primary data

The table III shows the purpose for which the respondents use these E-resources. It can be seen from the table that with regard purpose of using e-resources, it was found that majority of the respondents $32 \%$ are using the E-resources for their study, finding relevant information $20 \%$ for update subject knowledge $18 \%$, to prepare digital lesson plan $16 \%$, to prepare multimedia package $14 \%$. The above reveals that the respondents are more interested to use e-resources for their study.

From the table IV Problems seem to exist in each and every stage of resource material is it from print to electronic resources. There are some problems and difficulties of using of facilities required for accessing e-resources. They are slow accessibility, lack of computer and lack of knowledge, $30 \%$ of respondents stated that slow accessibility and $22 \%$ of lack of computer.

TABle V LeVEl Of USER SATISFACTION ABOUT E-RESOURCES

\begin{tabular}{|l|c|c|}
\hline User Opinion & Respondents & Percentage \\
\hline Satisfied & 33 & 66 \\
\hline Not satisfied & 17 & 34 \\
\hline Total & 50 & 100 \\
\hline \multicolumn{2}{|c|}{ Source: Primary data }
\end{tabular}

The above table $\mathrm{V}$ clearly shows that $66 \%$ of the respondents are satisfied with using e-journals. Whereas $34 \%$ are not satisfied using the E-Resources. Perhaps some may prefer to use print materials as they seem and find it convenient.

\section{FINDINGS AND CONCLUSION}

The findings of the distribution of respondent's awareness of ICT resources reveal fact that $28 \%$ of the respondents have very good awareness of the ICT based respondents and services. And the distribution of respondents have purpose of using e-resources reveal that $32 \%$ are using the EResources for their study, finding relevant information $20 \%$, for update subject knowledge $18 \%$ to prepare digital lesson plan $16 \%$, to prepare multimedia package $14 \%$. The above that the respondents are more interested to use e-resources for their study.

\section{REFERENCES}

[1] Kandasamy S (2019). Usage of E-source and E-journals by the students of Manonmaniam Sundaranar University: A Study. Two days International Seminar on Changing Scenario of Publishing Industries and the role of Librarians, Manonmaniam Sundaranar University.157-162.

[2] Maria Anna Jankowska. (2004). Identifying University professors: Information needs in the challenging environment of Information and communication Technology. The Journal of Academic Librarianship, 30(1), 51-66.

[3] Mounisamy, P., \& Swaroopa Rani, B.S. (2005). Evaluation of usage and usability of e-journals. SRELS Journal of Information Management, 42(2), 35-42.

[4] Poongodi K., \& Santhi J. (2014).Use and impact of ICT resources in Sri Sarada College for women, Salem, proceeding of the National Seminar on Reaching the Unreached, 265. 